\title{
Problems of organization
}

THE neurosciences are proud to call themselves an interdisciplinary gathering of people. But neuroscientists themselves often overlook the extent over which their component disciplines are spread. The field has its roots in clinical medicine. Physiology entered the scene only relatively recently, perhaps a century ago. But now, all kinds of disciplines have a finger in the pie, straightforward chemists and information scientists for example.

\section{Growth}

The neuroscientists also often forget how quickly their field has grown in the past decade or so, and how in the process it has been transformed. Until the mid-1950s or thereabouts, neuroscientists were typically people working in small laboratories, pursuing particular investigations in the time they had to spare from their other duties in the classroom and the committee room. The notion that there might be as much scope, in the understanding of how nervous systems work, for a transformation of professional opinion as there had been in molecular biology in the early 1950 s, was reluctantly accepted by the scientific community and by the grantmaking agencies. It is also fair to say that even at this late stage, many practitioners regret that their field of interest has become the excited (and excitable) community that it now is.

Thus the American Society for Neuro- science now boasts of 7,000 members. Many universities and other academic institutions now boast of an institute of neuroscience. (Johns Hopkins University and University College London have thus been blessed in the past year.) The standard claim on public attention (and the grantmaking agencies) is that more neuroscience will in due course mean less psychiatric illness, less drug addiction and possibly even an amelioration of mental defect.

\section{Problems}

Two problems arise. First, the neurosciences are probably by their nature destined to remain interdisciplinary. Intellectually, what this means is that students and postdoctoral fellows, trained perhaps as neurosurgeons, biochemists, molecular biologists and physiologists, will continue to provide the energy with which the understanding of nervous function is deepened. Of necessity, these recruits to what are called the neurosciences retain their affiliations and their skills. And there is no sense in the reasoning that the barriers between them can be broken down by renaming university departments responsible for undergraduate teaching.

Second, given the nature of the problem, the neurosciences are likely always to require that practitioners should work with specialized techniques in relatively narrow fields. Umbrella organizations, either the American Society for Neuroscience or
Professor F.O. Schmitt's personal creation, the Neurosciences Study Program, have a useful role to play in providing forums for discussion, but their influence is necessarily modest.

\section{Communication}

So may it be that what the field is most in need of is not more money or more people but a more durable method of communication than those with which it is now provided? Chemists, after all, rarely read the literature of the clinical sciences. Information scientists are attracted to problems of the nervous system only accidentally, when they happen to come across some reference in von Neumann, Shannon or even Schrödinger. Inevitably, the trouble is that such a vehicle for communication could not be a formal scientific journal; it would have to be, instead, a way of making people confront each other's problems.

\section{Reconciliation}

There are also geographical or cultural differences to be reconciled. Europeans like to think that they have invented most of the techniques that matter (but see ref. 44), and that Americans have jumped on the bandwagons thus set in motion; Americans, on the other hand, rightly suppose that they have made the only effective use of the tools at their disposal if, as seems likely, the pace of growth of employment in the neurosciences is likely to be less in future than in the past, can the machinery of communication remain as chauvinistic as it is?

\section{References}

1. Exodus 5:7.

2. Marr, D. Phil. Trans, R. Soc. B275, 483 (1976).

3. Cole, K.S. Archs Sci. Physiol. 3, 253 (1949).

4. Hodgkin, A.L. \& Katz, B. J. Physiol., Lond. 108, 37 (1949).

5. Hodgkin, A.L.\& Huxley, A.F. J. Physiol., Lond. 117,500 (1952).

6. Katz, B. \& Miledi, R. Nature 962, 226 (1970)

7. Neher, E. \& Sakmann, B. Nature 260, 16 (1981).

8. McBurney, R. Nature (News and Views) 290, 16 (1981).

9. Schinder, A. \& Quast, U. Proc. natn. Acad. Sci. U.S.A. 77, 3052 (1980)

10. Neher, E. \& Steinbach, J.H. J. Physiol., Lond. 277, 153 (1978).

11. Spector, M., Pepinsky, R.B., Vogt, V.M. \& Racker, E. Cell 25, 9 (1981).

12. Klingenberg, M. Nature 290, 449 (1981).

13. Kyte, J. Nature 292, 201 (1981).

14. Glynn, I.M. \& Richards, D.E. J. Physiol., Lond. 313, $31 \mathrm{P}$ (1981).

15. Fatt, P. \& Katz, B. J. Physiol., Lond. 115, 320 (1951).

16. Bennett, M.V.L. in Cellular Biology of Neurones (ed. Kandel, E.) (Williams \& Wilkins, Philadelphia, 1976).

17. Unwin, P.N.T. \& Zampighi, G. Nature 283, 545 (1980).

18. Katz, B. \& Miledi, R., J, Physiol., Lond. 224, 665 (1972).
19. Miledi, R., Parker, I. \& Schalow, G. J. Physiol., Lond. 300, 197 (1980).

20. Barker, J.L. \& Ransom, B.R. J. Physiol., Lond. 280, 331 (1978).

21. Alger, B.E. \& Nicoll, R.A. Nature 281, 315 (1979).

22. Skrede, K.Kr. \& Westgaard, R.H. Brain Res. 35, 589 (1971).

23. Schwartzkroin, P.A. Brain Res. 85, 423 (1975).

24. Barker, J.L. \& McBurney, R.N. Nature 277, 234 (1979).

25. Nicoll, R.A., Alger, B.E. \& Jahr, C.H. Nature 287, 22 (1980).

26. Katz, B. \& Miledi, R. J. Physiol., Lond. 198, 535 (1967).

27. Del Castillo, J. \& Katz, B. J. Physiol., Lond. 124, 560 (1954).

28. Raftery, M.A., Hunkapiller, M.W., Strader, C.D. \& Hood, L.E. Science 208, 1454 (1980).

29. Schindler, H. \& Quast, U. Proc. natn. Acad. Sci. U.S.A. 77, 3052 (1980)

30. Nelson, N., Anholt, R., L.indstrom, J. \& Montal, M. Proc. natn. Acad. Sci. U.S.A. 77, 3057 (1980).

31. Patrick, J. \& I.indstrom, J. Science 180, 871 (1973).

32. Hughes, J. et al. Nature 258, 577 (1975).

33. Burnstock, G. Pharmac. Rev. 21, 247 (1969).

34. Burnstock, G. (ed.) Receptors and Recognition Ser. B, Vol. 12 (Chapman \& Hall, London, (1981).

35. Kaufman, S. et al. New Engl. J. Med. 299, 673 (1978).
36. Kapatos, G. \& Kaufman, S. Science (in the press).

37. Kandel, E.R. \& Schwartz, J.H. Science (in the press).

38. A review of this work by E. Kandel will appear in a forthcoming issue of Nature.

39. Cooper, I..N. in The Organization of the Cerebral Cortex (eds Schmitt, F.O. et al.) (MIT Press, 1981).

40. Kristensson, K., Olsson, Y. \& Sjöstrand, J. Brain Res. 32, 399 (1971).

41. Gilbert, C.D. \& Wiesel, T.N. Nature 280, 120 (1979).

42. Stewart, W.D. Nature 292, 17 (1981).

43. Trisler, D.G., Schneider, M.D. \& Nirenberg, M. Proc. natn. Acad. Sci. U.S.A. 78, 2145 (1981).

44. Sokoloff, L. et al. J. Neurochem. 28, 897 (1977).

45. Kennedy, C. et al. Proc. natn. Acad. Sci. U.S.A. 78, 3950 (1981).

46. Cowey, A. in The Organization of the Cerebral Cortex (eds Schmitt, F.O. et al.) (MIT Press, 1981).

47. Zeki, S.M. Nature 274, 423 (1978).

48. Zeki, S.M. Nature 284, 412 (1980).

49. Marr, D. \& Nishihara, H.K. Technol. Rev. 81, 1 (1978).

50. Sutherland, N.S. Nature 278, 395 (1979)

51. Crick, F.H.C., Marr, D. \& Poggio, T. in The Organization of the Cerebral Cortex (eds Schmitt, F.O. et al.) (MIT Press, 1981). 